\title{
Fungal Isolates from the Honey Samples Collected from Retail Outlets in Southwestern Nigeria
}

\author{
Abel Adebayo Ayansola (Corresponding Author) \\ Senior Research Fellow, Entomology Unit, Natural History Museum \\ Obafemi Awolowo University, Ile-Ife, Nigeria
}

Tel: 234-803-352-9966Ｅ-mail: aaayansola@yahoo.com

Received: June 18, 2012 Accepted: July 4, 2012

doi:10.5296/jbls.v3i1.1974 URL: http://dx.doi.org/10.5296/jbls.v3i1.1974

\begin{abstract}
The study investigated the fungal composition of honey samples collected from six states in Southwestern Nigeria. Eighteen honey samples were screened in each state giving an overall total of 108 samples for the six states. The number of fungal species were determined and the microphotograph of colonial appearance of each was taken with Toshiba camera HD 1080P, 4X Digital Zoom. The morphological appearance of the fungal isolates as seen under the microscope were drawn and described.Seven species of fungi were isolated. The occurrence of the different species varied from one state to another. However, out of the seven species, only one, Trychophyton rubrum is pathogenic, and this is the first record of a pathogenic fungus from honey samples in Nigeria.
\end{abstract}

Keywords: Fungal isolates, Honey, Colonial appearance, Southwestern Nigeria

\section{Introduction}

The best known hive product is honey, which is valued both as a food and as a folk medicine. Honey is the primary hive product. It is basically nectar from which the bees have evaporated most of the water content. In converting the nectar to honey, the bees also have enzymes which serve mainly to break complex sugar molecules down into simple sugar molecules. The greatest nutritional attribute of honey is that it consists of simple sugars, which do not need to be digested but are assimilated directly by the body. This makes honey a quick energy source. Honey has numerous uses and functional applications worldwide such as in food systems, religious and cultural ceremonies as well as in human and veterinary medicine (Cooper et al., 2002; Eileen De Mars, 2003).

The major concern of honey quality is to ensure that honey is authentic in respect to the legislative requirements. According to the definition of the Codex Alimentarius standard for 
honey (Codex Alimentarius Commission, 2001) and other international honey standards (EU Council, 2002) honey shall not have any added food ingredient nor shall any particular constituent be removed from it. Honey shall not have any objectionable matter, flavour, aroma or taint from foreign matter during its processing and storage. The honey shall not have begun to ferment. No pollen or constituent particular to honey may be removed except where this is unavoidable in the removal of foreign organic matter. Honey shall not be heated or processed to such an extent that its essential composition is changed and/or its quality impaired (Codex Alimentarius Commission, 2001, EU Council, 2002).

The presence of micro-organisms in honey can sometimes influence the stability of the product and its hygienic quality. Normal honey must lack pathogenic micro-organisms or micro-organisms that produce enteric illnesses (Popa et al., 2009). In honey samples collected from local markets in Romania, there was a presence of Bacillus sp and eight types of fungi. In Nigeria, however, there is dearth of information on the fungal composition of honey samples collected from local markets. This explains the rationale behind the present study. The objective of this study therefore was to determine the fungal composition of honey being sold in local markets of southwestern Nigeria.

\section{Materials and Methods}

\subsection{Identification of Fungal Isolates from Honey Samples}

\section{Total Heterotrophic Fungi (THF)}

One millilitre of each honey sample was added to $9.0 \mathrm{ml}$ of sterile distilled water in a MacCarthney bottle, respectively, and vigorously agitated more uniformly (Dilution; 1/10 $\mathrm{V} / \mathrm{V})$. Then $0.1 \mathrm{ml}$ was diluted hundred folds, $3 \mathrm{X}$, in a set of test-tubes, each containing $9.9 \mathrm{ml}$ sterile distilled water. One millilitre of each dilution was plated out in duplicates, employing the use of Malt extract agar medium (sterile) kept in molten form. Pour plate method was adopted.

The culture plates were incubated uninvertedly and aerobically at $30^{\circ} \mathrm{c}$ for $5-7$ days (until the plates showed no further increase in the number of fungal colonies).

The culture plate in which the number of colonies was less than 10 was selected.

\subsection{Identification of Fungal Isolates from Honey Samples}

Moulds and yeasts isolates were identified by their growth characteristics (i.e texture, pigmentation, form, spore formation, etc.) and morphology through staining techniques using Lactophenol cotton blue (for moulds) and Gram staining (for yeasts). The prepared slides were examined under a compound microscope for the morphological appearances of the fungi and drawn at a magnification of X 400 .

Drawings of the various structures (i.e Sporangium, sporangiophores, columellae, mycelium, spores, etc.) of each isolate were made and compared with drawings of described commonly encountered moulds and yeasts (Collins and Lyne, 1979).

Microphotographs were taken with Toshiba Camera HD 1080P, 4X Digital Zoom. 


\section{Macrothink}

\section{Results}

3.1 Species Number and Occurrence of Fungi Isolated from Honey Samples in Six States of South-western Nigeria

Seven species of fungi were isolated from honey samples in six states of southwestern Nigeria (Table 1). Their occurrence in the six states were presented in Table 2. Cladosporium wernecki was found in Ekiti, Ondo and Oyo state honey samples. Cephalosporium sp. was detected in the honey samples of Ekiti, Ogun and Osun states. Mucor mucedo occurred in Lagos, Ondo, Osun and Oyo states' honey samples. Rhizopus japonicus was found in Ogun, Ondo and Oyo states' honey samples. Cladosporium herbarum was detected only in Ondo state honey samples. Trichophyton rubrum occurred only in Ondo state while Scopulariopsis brevicaulis occurred only in Oyo state honey samples.

\subsection{Mean Total Fungi Counts in Honey Samples}

The mean total fungi counts in honey samples from the six states of South-western Nigeria were presented in Table 3. The mean total fungi for Ekiti, Lagos and Ogun states were 40.0 $\mathrm{cfu} / \mathrm{ml}, 10.0 \mathrm{cfu} / \mathrm{ml}$, and $15.0 \mathrm{cfu} / \mathrm{ml}$ respectively. The recorded mean total fungi in honey samples from Ondo, Osun and Oyo states were $85.0 \mathrm{cfu} / \mathrm{ml}, 45.0 \mathrm{cfu} / \mathrm{ml}$ and $2.0 \mathrm{X} 10^{3} \mathrm{cfu} / \mathrm{ml}$ respectively.

Table 1. The species list of fungi isolated from the honey samples in six states of South-western Nigeria

\begin{tabular}{|l|}
\hline \multicolumn{1}{|c|}{ Fungi } \\
\hline Cladosporium wernecki \\
\hline Cephalosporium sp. \\
\hline Mucor mucedo \\
\hline Cladosporium herbarum \\
\hline Rhizopus japonicas \\
\hline Trichophyton rubrum \\
\hline Scopulariopsis brevicaulis \\
\hline
\end{tabular}

Table 2. Occurrence of fungi isolated from honey samples in six states of South-western Nigeria

\begin{tabular}{|l|c|c|c|c|c|c|c|}
\hline State & $\begin{array}{l}\text { Cladosporium } \\
\text { Wernecki }\end{array}$ & $\begin{array}{l}\text { Cephalosporium } \\
\text { sp. }\end{array}$ & $\begin{array}{l}\text { Mucor } \\
\text { mucedo }\end{array}$ & $\begin{array}{l}\text { Rhizopus } \\
\text { japonicus }\end{array}$ & $\begin{array}{l}\text { Cladosporium } \\
\text { herbarum }\end{array}$ & $\begin{array}{l}\text { Trychophyton } \\
\text { rubrum }\end{array}$ & $\begin{array}{l}\text { Scopulariopsis } \\
\text { brevicaulis }\end{array}$ \\
\hline Ekiti & + & + & - & - & - & - & - \\
\hline Lagos & - & - & + & - & - & - & - \\
\hline Ogun & - & + & - & + & - & - & - \\
\hline Ondo & + & - & + & + & + & + & - \\
\hline Osun & - & + & + & - & - & - & - \\
\hline Oуо & + & - & + & + & - & - & + \\
\hline
\end{tabular}

$+=$ Presence of fungi species

- = Absence of fungi species 
Table 3. Mean Microbial Profile of Honey samples collected from six states of South-western Nigeria

\begin{tabular}{|l|l|}
\hline State & THF $(\mathbf{c f u} / \mathbf{m l})$ \\
\hline Ekiti & 40.0 \\
\hline Lagos & 10.0 \\
\hline Ogun & 15.0 \\
\hline Ondo & 85.0 \\
\hline Osun & 45.0 \\
\hline Oyo & $2.0 \times 10^{3}$ \\
\hline
\end{tabular}

\section{THF - Total Heterotrophic Fungi}

cfu - Colony forming unit

\subsection{Colonial Characteristics of the Fungal Isolates}

\section{Trichophyton rubrum}

Grows as a bluffy colony but slowly; having a definite red pigment on the back. Both pigment production and spore formation may be slow (Plate 2)

\section{Scopulariopsis brevicaulis}

Forms a yellow to brown velvety colony on malt extract agar (Plate 4)

\section{Cladosporium herbarum}

A deep greenish black small heaped colonies

Young cultures are moist and yeast-like. Both are dark in colour when the culture plates are examined at the back (Plate 5)

\section{Cladosporium werneckii}

A deep greenish black small heaped colonies

Young cultures are moist and yeast-like. Both are dark in colour when the culture plates are examined at the back (Plate 5)

\section{Mucor mucedo}

The fungus is rapid growing, appearing white and later showed:

1. greyish sporangia

2. greyish brown sporangia, and

3. reddish sporangia (Plate 3).

\section{Rhizopus japonicus}




\section{Macrothink}

Journal of Biology and Life Science

ISSN 2157-6067 2012, Vol. 3, No. 1

Rapidly growing, white coloured fungus swarms over entire plate: then showed black spores varying in sizes depending on the species. (Plate 1)

\section{Cephalosporium sp.}

Produces a tough white colony, turning pale pink (Plate 6)

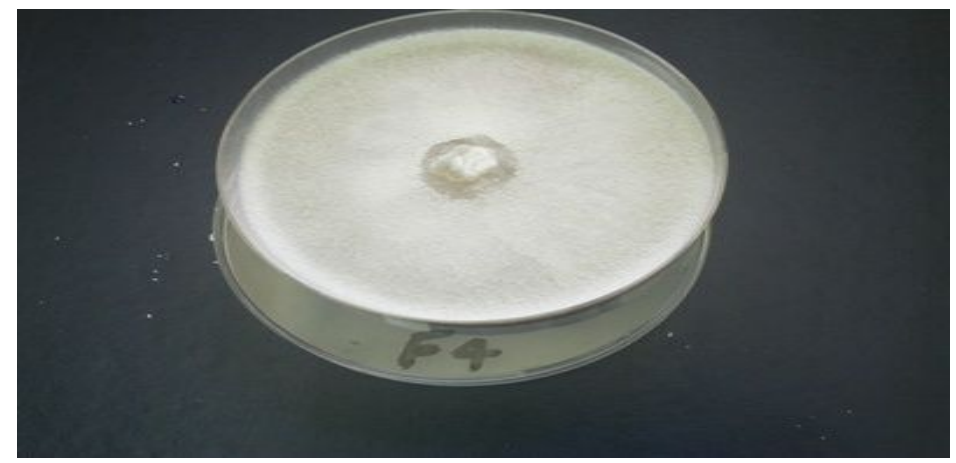

Plate 1. Colonial appearance of Rhizopus japonicus

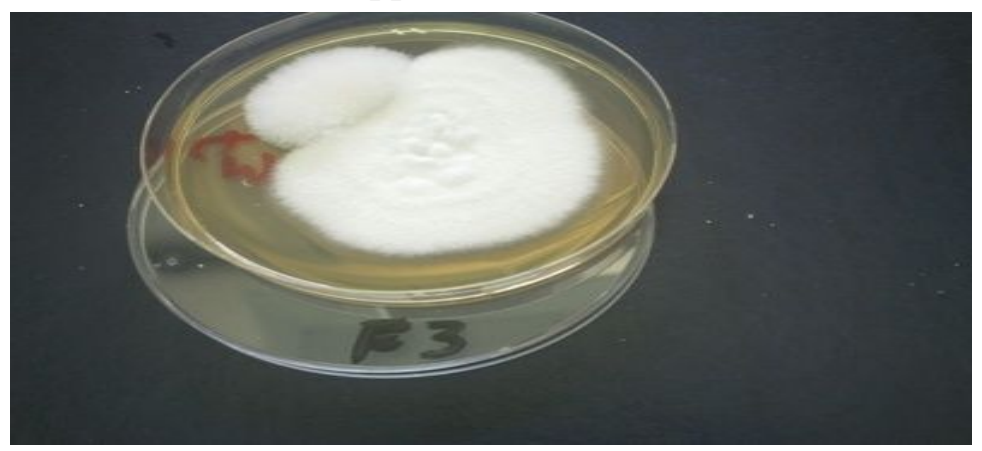

Plate 2. Colonial appearance of Trichophyton rubrum

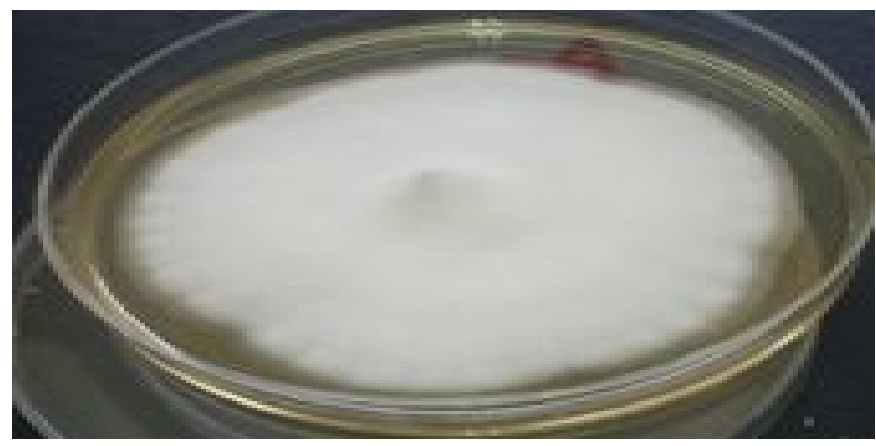

Plate 3. Colonial appearance of Mucor Mucedo

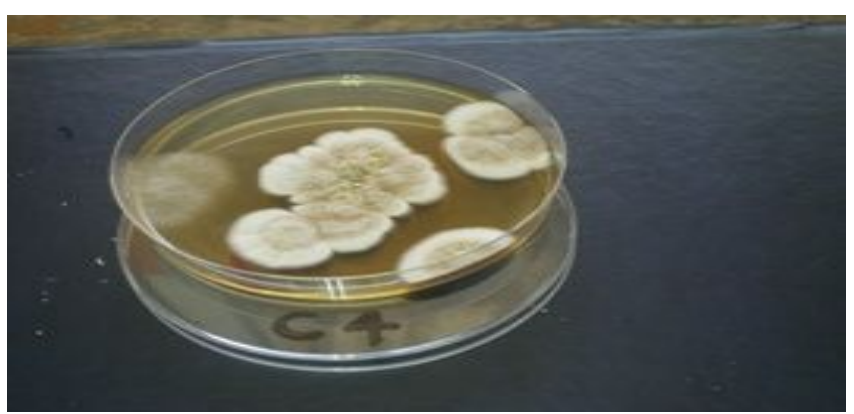

Plate 4. Colonial appearance of Scopulariopsis brevicaulis 


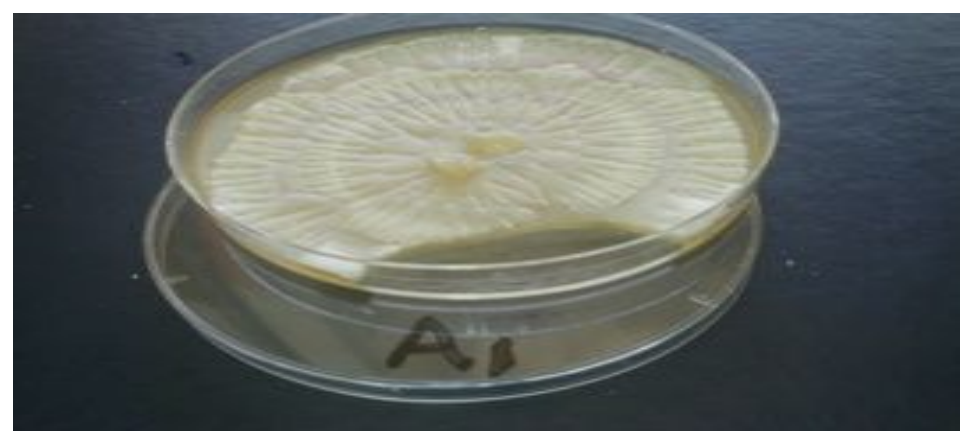

Plate 5. Colonial appearance of Cladosporium sp.

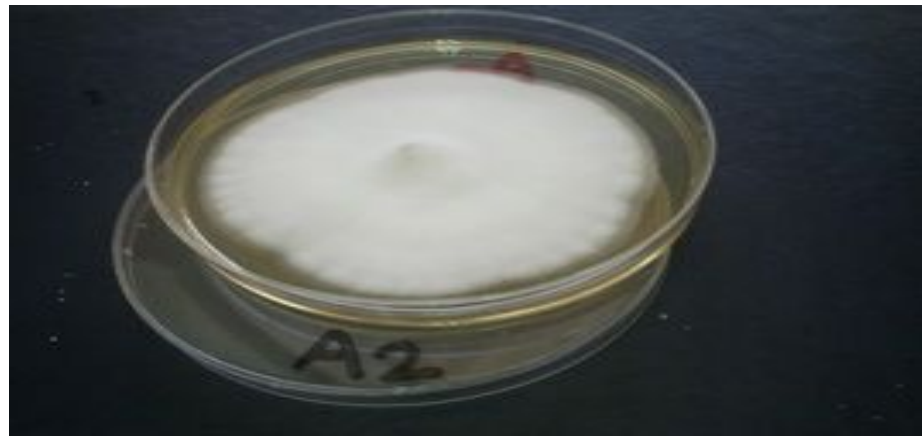

Plate 6. Colonial appearance of Cephalosporium sp.

3.4 Morphological Appearance of Fungal Isolates as Seen under the Microscope.

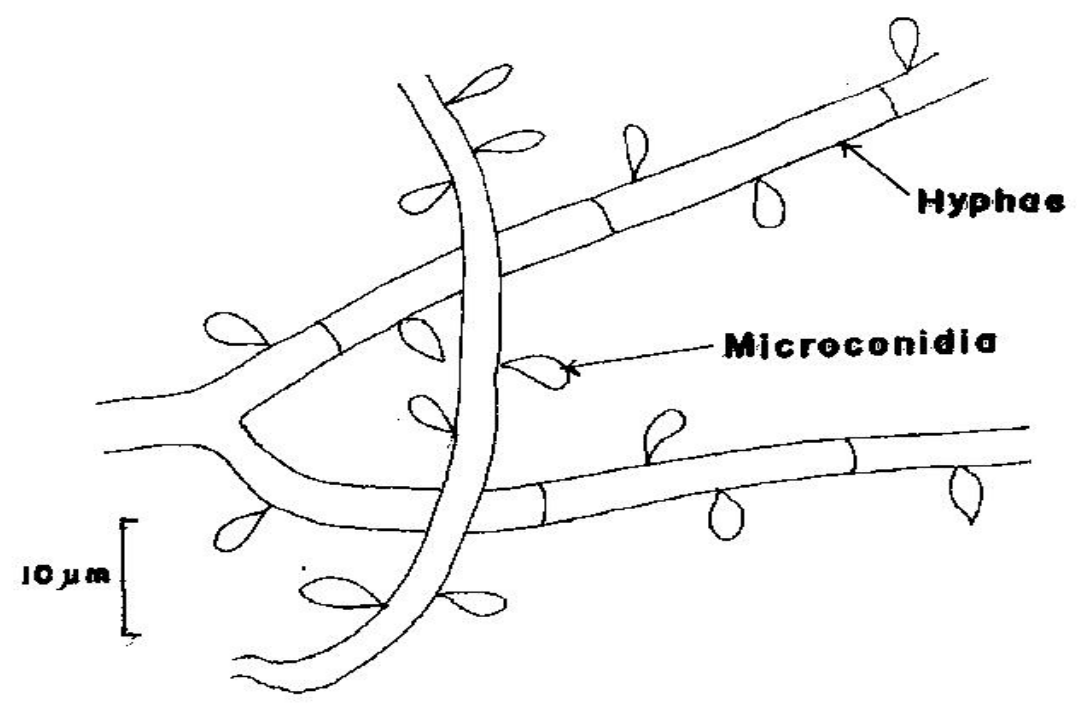

Figure 1. Morphological Appearance of Trichophyton rubrum

Microconidia are borne along the sides of the hyphae, but are rather elongated resembling barbed wire under a low-power microscope. 


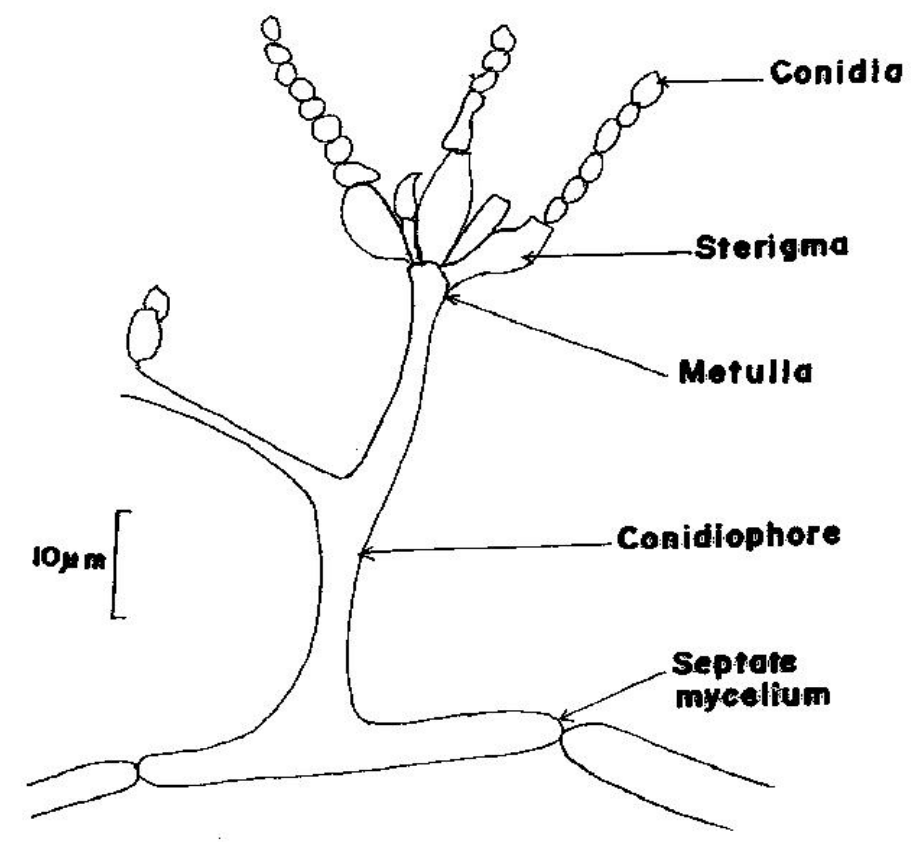

Figure 2. Morphological Appearance of Scopulariopsis brevicaulis

Similar to Penicillium spp. structurally

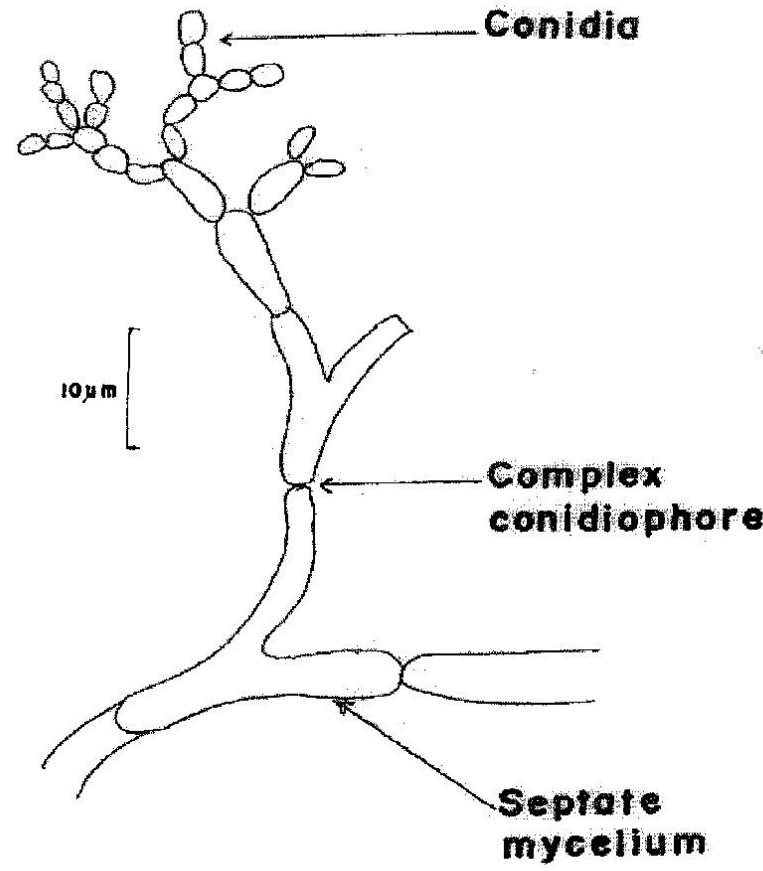

Figure 3. Morphological Appearance of Cladosporium sp.

Spores occur in large tree. Like clusters and develop at the end of complex conidiophores arising from a septate mycelium. 


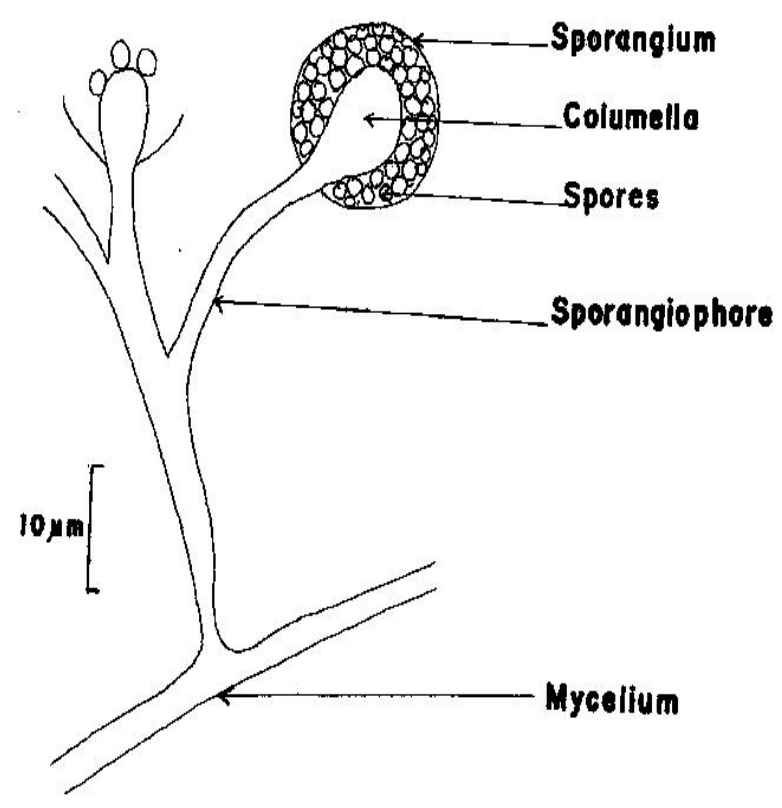

Figure 4. Morphological Appearance of Mucor mucedo

Spores are oval, non septate mycelium gives rise to single sporangium with a collumella.

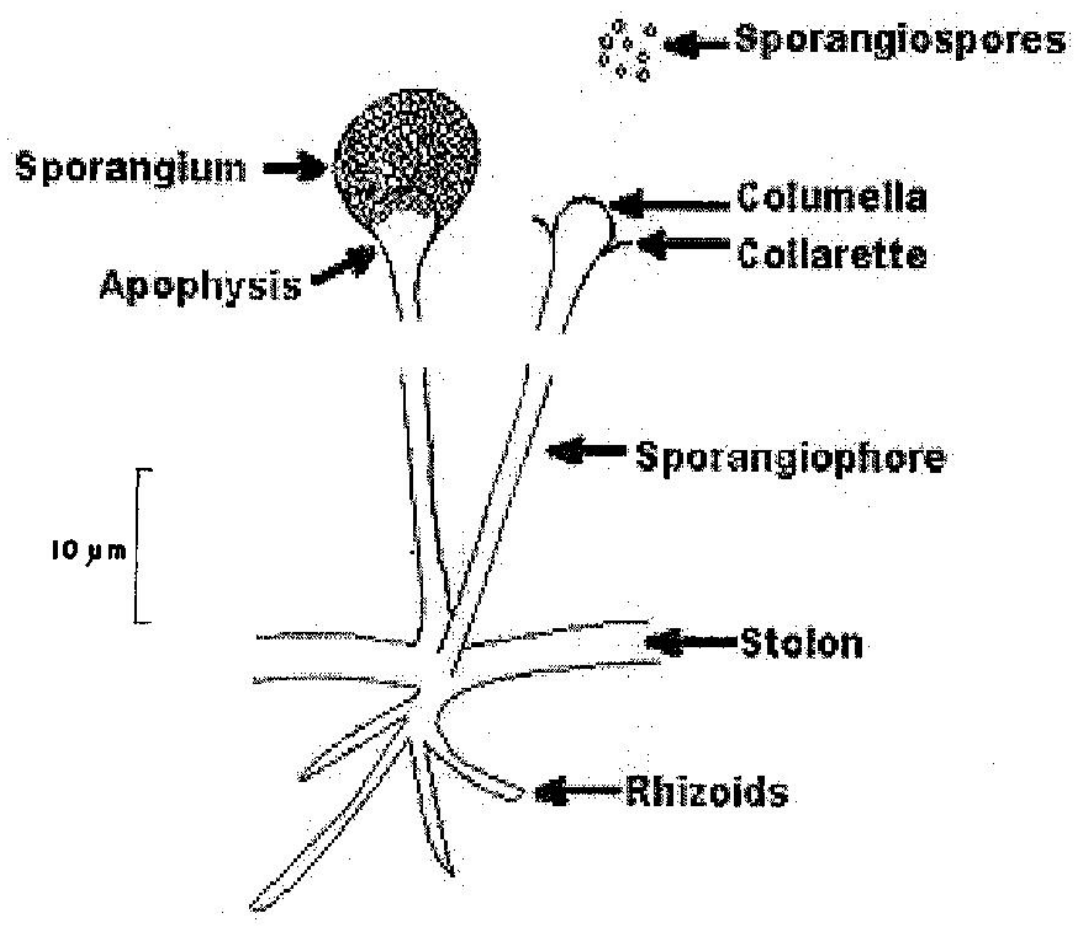

Figure 5. Morphological Appearance of Rhizopus japonicus

Non-septate mycelium gives rise to straight sporangiophores that terminate with black sporangium containing a colummella; root-like hyphae (rhizoids) penetrate the medium. 


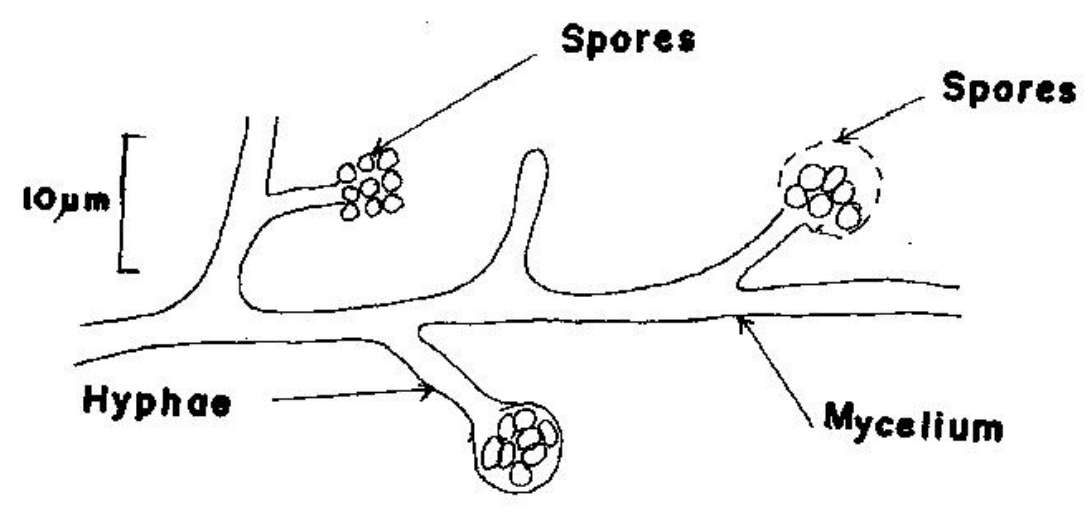

Figure 6. Morphological Appearance of Cephalosporium spp. (X400)

The slimy spores are borne in small balls on the end of slender hyphae

\section{Discussion}

All the honey samples from the six states of South-western Nigeria were contaminated with fungi. This confirms other findings that fungi and spore forming bacteria may be present in honey (Anonymous, 2003; Tchoumboue et al., 2007). Most works in Nigeria did not find fungi in Nigeria honey (Agwu and Okeke, 1997; Adebiyi et al., 2004; Lawal et al., 2009). However this may be due to the fact that the workers obtained their samples from the primary sources (bee farms). According to Popa et al. (2009), microbiological contamination during or after processing honey was demonstrated by the absence of the micro-organisms in the samples collected from primary sources and by the presence of bacterium (Bacillus sp) and eight types of fungi in the collected samples from local markets. This fact indicates the contamination from secondary sources during processing, packaging or intentional adulteration.

According to Tchoumboue et al. (2007), the contamination with fungi and bacteria indicate inadequate hygiene conditions during collecting, manipulating, processing and storing.

Microbial contamination during and or post processing can also result in spoilage or persistence of some fungi in honey (Anonymous, 2004). Similar contaminations of other foodstuffs obtained from the local markets have been reported (Angrey, 2001). The fungi present in West Cameroon honey samples indicate contamination from secondary sources, during handling or adulterations. This is confirmed by their absence in honey harvested from Bee research Farm of the University of Dschang (Miel campus), Cameroon where processing and handling are always carried out in good hygienic conditions.

Therefore, the microbiological quality of honey may serve as an indicator of the hygienic conditions under which the product was processed, handled and stored. 
Trichophyton rubrum species are causative agents of Dermatophytosis, Onychomycosis, Tinea barbae, Tinea capitis, Tinea corporis, Tinea cruris, Tinea faciei, Tinea pedis, and Tinea unguium. Trichophyton rubrum is the most widespread among the anthropophilic dermatophytes. Anthropophilic dermatophyte is found in association with humans. Trichophyton rubrum is the most common agent of tinea of the feet, hands, nails, groin, and the glabrous skin, however, the scalp is rarely infected. Animals are very infrequently infected as well (Anonymous, 2005).

\section{Conclusion}

All the honey samples in the six states contained heterotrophic fungi. The presence of heterotrophic fungi is an indication of unhygienic status of honey on sale by the retailers. This study is the first to report the presence of pathogenic fungus, Trichophyton rubrum in honey in Nigeria. The presence of pathogenic fungus necessitates an urgent need to monitor microbial status of marketed honey in South-western Nigeria.

\section{References}

Adebiyi, F. M., Akpan, I., Obiajunawa, E. T., \& Olaniyi, H. B. (2004). Chemical/Physical characterization of Nigerian honey. Pakistan J. Nutri., 3, 278-281.

Agwu, C.O.C. \& Okeke, G. (1997). Pollen analytical and thin-layer chromatographic study of honey from three savanna zones of northern Nigeria. Nigerian J. Botany, 10, 25-36

Angrey, D. (2001). Qualiite microbiologie des arachnids (Arachis hypogeal L.) Vendus sous forme d'amuse gueule dans quelques marches Camerounais et perception par la population des maladies liees a leur consummation. Memoire de fin d'etude, FASA, Universite de Dschang.

Anonymous. (2003). Honey research: properties of honey. Retrieved December 18, 2010, http:// www.nhb.org/properties/index.html

Anonymous. (2004). Bee Honey as a natural product. Almaleka; Retrieved June 10, 2010 from http://natural-products.almaleka.com/bproducts/honey/hl.htm

Codex Alimentarius Commission. (2001). Revised Codex Standard for Honey, Codex STAN 12-1981, Rev.1 (1987), Rev.2 (2001); FAO/WHO, 215 pp.

Collins, C.H., \& Lyne, P.M. (1979). Microbiological methods. Butterworths chaps. 31 and 32 Cooper, R.A., Molan, P.C., Harding, K.G. (2002). The sensitivity to honey of Gram positive cocci of clinical significance isolated from wounds. J. Appl. Microbio., 93, 857 - 863

Eileen, D. M. (2003). The importance of honey. National Honey Board, 650, 123 - 135. Retrieved January 10, 2011 from http://www. honey\%20bee\%20products.htm

EU Council. (2002). Honey and microbiological hazards Report of European Commission of Health and Consumer Protection Directorate-General, 1 - 40.

Lawal, R.A., Lawal A.K., \& Adekalu J.B. (2009). Physico-chemical Studies on Adulteration 
of Honey in Nigeria. Pakistan J. Bio. Sci., 12 (15), 1080-1084.

Popa, M., Vica, M., Axinte, R., Glevitzky, M., \& Varvara, S. (2009). Study concerning the honey qualities in Transylvania Region. Annales Universitatis Apulensis Series Oeconomica, 2, 1034-1040.

Tchoumboue, J., Awah-Ndukum, J., Fonteh, F.A., Dongock, N.D., Pinta, J., \& Mvondo, Z.A. (2007). Physico-chemical and microbiological characteristics of honey from sudan-guinean zone of West Cameroon. Africa J. Biotech., 6, 908-913.

\section{Copyright Disclaimer}

Copyright reserved by the author(s).

This article is an open-access article distributed under the terms and conditions of the Creative Commons Attribution license (http://creativecommons.org/licenses/by/3.0/). 